\title{
Association of blood-based transcriptional risk scores with biomarkers for Alzheimer disease
}

\author{
Young Ho Park, MD, PhD, Angela Hodges, PhD, Andrew Simmons, PhD, Simon Lovestone, PhD, \\ Michael W. Weiner, MD, SangYun Kim, MD, PhD, Andrew J. Saykin, PsyD,* and Kwangsik Nho, PhD,* \\ For the AddNeuroMed consortium and the Alzheimer's Disease Neuroimaging Initiative
}

Neurol Genet 2020;6:e517. doi:10.1212/NXG.0000000000000517

\section{Abstract}

\section{Objective}

To determine whether transcriptional risk scores (TRSs), a summation of polarized expression levels of functional genes, reflect the risk of Alzheimer disease (AD).

\section{Methods}

Blood transcriptome data were from Caucasian participants, which included $\mathrm{AD}$, mild cognitive impairment, and cognitively normal controls $(\mathrm{CN})$ in the Alzheimer's Disease Neuroimaging Initiative (ADNI, $n=661)$ and AddNeuroMed $(n=674)$ cohorts. To calculate TRSs, we selected functional genes that were expressed under the control of the $\mathrm{AD}$ risk loci and were identified as being responsible for $\mathrm{AD}$ by using Bayesian colocalization and mendelian randomization methods. Regression was used to investigate the association of the TRS with diagnosis (AD vs $\mathrm{CN}$ ) and MRI biomarkers (entorhinal thickness and hippocampal volume). Regression was also used to evaluate whether expression of each functional gene was associated with $\mathrm{AD}$ diagnosis.

\section{Results}

The TRS was significantly associated with $\mathrm{AD}$ diagnosis, hippocampal volume, and entorhinal cortical thickness in the ADNI. The association of the TRS with AD diagnosis and entorhinal cortical thickness was also replicated in AddNeuroMed. Among functional genes identified to calculate the TRS, CD33 and PILRA were significantly upregulated, and TRAPPC6A was significantly downregulated in patients with $\mathrm{AD}$ compared with $\mathrm{CN}$, all of which were identified in the ADNI and replicated in AddNeuroMed.

\section{Conclusions}

The blood-based TRS is significantly associated with $\mathrm{AD}$ diagnosis and neuroimaging biomarkers. In blood, CD33 and PILRA were known to be associated with uptake of $\beta$-amyloid and herpes simplex virus 1 infection, respectively, both of which may play a role in the pathogenesis of $\mathrm{AD}$.

\section{Classification of evidence}

The study is rated Class III because of the case control design and the risk of spectrum bias.

\author{
Correspondence \\ Dr. Nho \\ knho@iu.edu \\ or Dr. Saykin \\ asaykin@iu.edu
}

\section{MORE ONLINE}

$\rightarrow$ Class of Evidence

Criteria for rating

therapeutic and diagnostic

studies

NPub.org/coe

\footnotetext{
*These authors contributed equally to the manuscript.

From the Department of Radiology and Imaging Sciences (Y.H.P., A.J.S., K.N.), and the Indiana Alzheimer Disease Center, Indiana University School of Medicine, Indianapolis; Department of Neurology (Y.H.P.), Seoul National University Bundang Hospital and Seoul National University College of Medicine, Seongnam, Republic of Korea; Institute of Psychiatry, Psychology \& Neuroscience (A.H., A.S.), King's College London, United Kingdom; Department of Psychiatry (S.L.), University of Oxford, United Kingdom; Departments of Radiology, Medicine, and Psychiatry (M.W.W.), University of California-San Francisco; Department of Veterans Affairs Medical Center (M.W.W.), San Francisco, CA; Department of Medical and Molecular Genetics (A.J.S.), Indiana University School of Medicine, Indianapolis; and Center for Computational Biology and Bioinformatics (K.N.), Indiana University School of Medicine, Indianapolis.

Go to Neurology.org/NG for full disclosures. Funding information is provided at the end of the article.

The Article Processing Charge was funded by the NIH.

Data used in preparation of this article were obtained from the Alzheimer's Disease Neuroimaging Initiative (ADNI) database (adni.loni.usc.edu). As such, the investigators within the ADNI contributed to the design and implementation of ADNI and/or provided data but did not participate in analysis or writing of this report. A complete listing of ADNI investigators can be found at: adni.loni.usc.edu/wp-content/uploads/how_to_apply/ADNI_Acknowledgement_List.pdf. 


\section{Glossary}

$\mathbf{A} \beta=\beta$-amyloid $\mathbf{A D}=$ Alzheimer disease ADAS- $\operatorname{cog} 13$ = Alzheimer's Disease Assessment Scale Cognitive Subscale 13; ADNI = Alzheimer's Disease Neuroimaging Initiative; CDR = Clinical Dementia Rating; $\mathbf{C I}=$ confidence interval; $\mathbf{C N}=$ cognitively normal controls; $\mathrm{eQTL}=$ expression quantitative trait loci; $\mathbf{g B}=$ glycoprotein $\mathrm{B}$; GWAS = genome-wide association study; HSV-1 = herpes simplex virus 1; ITIM = immunoreceptor tyrosine-based inhibitory motif; $\mathbf{L D}$ = linkage disequilibrium; MAF = minor allele frequency; $\mathbf{M C I}=$ mild cognitive impairment; $\mathbf{M M S E}=$ Mini-Mental State Examination; $\mathbf{O R}=$ odds ratio; QC = quality control; SMR = summary data-based mendelian randomization; SNP = single nucleotide polymorphism; SUV = standardized uptake value; TRS $=$ transcriptional risk score.

Alzheimer disease (AD) has a strong genetic component. ${ }^{1}$ Previous studies suggest that the relative risk of $\mathrm{AD}$ for those with at least 1 first-degree relative with $\mathrm{AD}$ is 3.5 (95\% confidence interval $[\mathrm{CI}] 2.6-4.6)^{2}$ and possibly as high as 7.5 (95\% CI 3.3-16.7) when 2 or more first-degree relatives are affected. $^{2}$ Large-scale genome-wide association studies (GWASs) have identified more than $20 \mathrm{AD}$ risk loci. ${ }^{3,4}$ However, it has been challenging to perform functional studies of $\mathrm{AD}$ risk loci to identify underlying molecular mechanisms.

It is known that trait-associated single nucleotide polymorphisms (SNPs) are likely to be expression quantitative trait loci (eQTL). ${ }^{5}$ The risk SNPs identified by GWASs may contribute to the pathogenesis of disease by controlling expression of nearby genes, and the transcriptomic analysis to identify target genes regulated by the risk SNPs has been used to uncover molecular mechanisms. ${ }^{6}$ Transcriptional risk scores (TRSs), a summation of polarized expression levels of functional genes that reflect the risk of disease, have been proposed and used to distinguish patients with Crohn disease from healthy subjects. ${ }^{6}$

Here, we calculated the TRS using blood-based transcriptomic profiles regulated by $\mathrm{AD}$ risk loci to investigate whether the TRS demonstrates an $\mathrm{AD}$ diagnosis group difference and is associated with $\mathrm{AD}$-related neuroimaging biomarkers in 2 independent cohorts. In addition, we evaluated whether target genes selected to calculate the TRS are associated with $\mathrm{AD}$ diagnosis.

\section{Methods}

\section{Participants}

Data used in the study were obtained from Caucasian participants $(\mathrm{AD}$, mild cognitive impairment $[\mathrm{MCI}]$, and cognitively normal controls $[\mathrm{CN}]$ ) in the Alzheimer's Disease Neuroimaging Initiative (ADNI) and AddNeuroMed cohorts as discovery and replication samples, respectively. The ADNI was launched in 2003 as a public-private partnership, led by Principal Investigator Dr. Michael W. Weiner. ${ }^{7}$ The primary goal of the ADNI has been to test whether serial MRI, PET, other biological markers, and clinical and neuropsychological assessment can be combined to accurately capture the progression of MCI and early AD. The AddNeuroMed is a cross European, public/private consortium developed for $\mathrm{AD}$ biomarker discovery. ${ }^{8} \mathrm{AD}$ was diagnosed clinically according to the NINCDS/ADRDA criteria for probable AD in ADNI and AddNeuroMed. ${ }^{9}$ MCI was diagnosed when there was objective memory impairment but without meeting the criteria for dementia. ${ }^{7,8}$ In ADNI, participants with MCI had a MiniMental State Examination (MMSE) score between 24 and 30 , memory performance approximately $1 \mathrm{SD}$ below expected education adjusted norms, and a Clinical Dementia Rating (CDR) score of 0.5. In AddNeuroMed, participants with MCI had an MMSE score between 24 and 30 and a CDR score of 0.5 .

\section{Genotyping and imputation}

Genotyping for the ADNI and AddNeuroMed was performed using blood DNA samples and a combination of Illumina GWAS array platforms (Illumina Human610-Quad BeadChip, Illumina HumanOmni Express BeadChip, and Illumina HumanOmni 2.5M BeadChip). ${ }^{10,11}$ APOE genotyping was separately conducted using previously described standard methods to yield the APOE $\varepsilon 4$ allele defining SNPs (rs429358, rs7412). ${ }^{10,11}$ Using PLINK 1.9 (cog-genomics. org/plink2/), ${ }^{12}$ we also performed standard quality control (QC) procedures for samples (sex inconsistencies and sample call rate $<95 \%$ ) and SNPs (SNP call rate $<95 \%$, HardyWeinberg $p$ value $<1 \times 10^{-6}$, and minor allele frequency $[\mathrm{MAF}]<1 \%)$ as described previously. ${ }^{13}$ Then, to prevent spurious associations due to population stratification, we used multidimensional scaling analysis to select only non-Hispanic participants of European ancestry that clustered with HapMap CEU (Utah residents with Northern and Western European ancestry from the Centre d'Etude du Polymorphism Humain collection) or Toscani in Italia populations. ${ }^{14,15}$ After QC procedures, because the 2 cohorts used different genotyping platforms, we imputed ungenotyped SNPs separately in each platform using $\mathrm{MaCH}$ with the Haplotype Reference Consortium data as a reference panel. ${ }^{16,17}$ Following the imputation, we imposed an $r^{2}$ value of 0.30 as the threshold to accept the imputed genotypes.

Blood-based RNA expression microarray profiling The PAXgene Blood RNA Kit (Qiagen Inc., Valencia, CA) was used to purify total RNA from whole blood collected in a PAXgene Blood RNA Tube. ${ }^{10,18}$ The Affymetrix Human 
Genome U219 Array (Affymetrix, Santa Clara, CA) in the ADNI and the Illumina Human HT-12 v3 Expression BeadChips (Illumina Inc., San Diego, CA) in AddNeuroMed were used for expression profiling. ${ }^{10,18}$ All probe sets were mapped and annotated to the human genome (hg19). Raw expression values were preprocessed using the robust multichip average normalization method and robust spline normalization method in the ADNI and AddNeuroMed, respectively. ${ }^{19,20}$ We evaluated discrepancies between the reported sex and sex determined from sex-specific gene expression data, including XIST and USP9Y. We also determined whether SNP genotypes were matched with genotypes predicted from gene expression data. ${ }^{19}$ After QC, the RNA expression profiles, which contained 21,150 probes in the ADNI and 5,141 probes in AddNeuroMed, were preadjusted with batch effects and RNA integrity number values using linear regression. Finally, if a gene contained more than 1 microarray probe, we selected only the probe with the greatest variance.

\section{Selection of AD-associated SNPs and candidate genes}

To select AD-associated SNPs, we started by considering 29 SNPs that had genome-wide significant associations $(p<5 \times$ $10^{-8}$ ) in a recent AD GWAS meta-analysis ${ }^{3}$ and 406 SNPs that were in strong linkage disequilibrium (LD) $\left(r^{2}>0.8\right)$ with them. Then, after pruning the 435 SNPs by removing SNPs in LD $\left(r^{2}>0.1\right)$ using LDlink 3.7 (ldlink.nci.nih.gov), we were left with $24 \mathrm{AD}$-associated SNPs. In addition, we selected SNPs (2,533, 3,288, 4,968, 9,909, 29,894, and $175,262 \mathrm{SNPs})$ that were associated with $\mathrm{AD}$ in the GWAS with $p$ values less than $1 \times 10^{-7}, 1 \times 10^{-6}, 1 \times 10^{-5}, 1 \times 10^{-4}, 1$ $\times 10^{-3}$, and $1 \times 10^{-2}$, respectively. ${ }^{3}$ After pruning, we had 92, $115,188,617,3,237$, and 20,978 $\mathrm{AD}$-associated SNPs, respectively. Then, using the public blood eQTL database from CN (genenetwork.nl/bloodeqtlbrowser), we identified candidate genes that are located within $\pm 1 \mathrm{Mbp}$ of $\mathrm{AD}$ associated and pruned SNPs that have a direct impact on gene expression (false discovery rate-corrected $p<0.05$ for eQTL). ${ }^{20,21}$

\section{Selection of target genes from AD-associated candidate genes using COLOC and summary data-based mendelian randomization}

A significant association between an SNP and a gene from the aforementioned integration of $\mathrm{AD}$ GWAS summary statistics and the blood eQTL database does not necessarily imply that a gene is associated with $\mathrm{AD}$. Therefore, to determine whether a gene regulated by an SNP is associated with $\mathrm{AD}$, we estimated the colocalization of signals using COLOC and summary data-based mendelian randomization (SMR). ${ }^{6}$ We applied both methods to distinguish target genes from candidate genes. COLOC uses a Bayesian framework that calculates posterior probabilities for hypotheses about the presence and sharing of causal SNPs by GWAS summary statistics and eQTL data. ${ }^{22}$ We selected genes supporting the hypothesis of 1 causal SNP common to both $\mathrm{AD}$ diagnosis $(\mathrm{AD}$ vs $\mathrm{CN})$ and gene expression with $80 \%$ or greater posterior probability $\left(H_{4}>80 \%\right){ }^{6}$ The SMR combines GWAS summary statistics and eQTL data to identify target genes whose expression levels are associated with $\mathrm{AD}$ diagnosis $(\mathrm{AD}$ vs $\mathrm{CN}) .{ }^{23}$ Multiple testing correction was performed using the Bonferroni method $\left(p_{S M R}<\right.$ $\left.8.4 \times 10^{-6}\right)$.

\section{Calculation of the TRS}

We calculated the TRS using the following steps. ${ }^{6}$ First, we transformed expression levels of each gene into a normal distribution with a mean of 0 and variance of 1 . Then, we used the eQTL activity of AD-associated SNPs to infer the direction of risk at each gene selected for the TRS. The concept of high expression and low expression was used to denote whether an $\mathrm{AD}$ risk allele was associated with increased (high expression) or decreased (low expression) gene expression levels. In rare cases, genes were labeled as both high expression and low expression because the same gene could be associated with different SNPs in the eQTL data. Genes with both labels were excluded from the analysis. Next, we polarized gene expression levels by changing the sign of the expression levels ( $z$-score) for genes labeled as low expression. Thus, elevated risk from gene expression, irrespective of the direction of risk, could be additively incorporated in the TRS. Finally, we calculated the TRS for each individual by summing the polarized $z$-scores over the corresponding genes.

\section{Statistical analysis}

We performed logistic regression analysis to compare the TRS of $\mathrm{AD}$ with $\mathrm{CN}$ and made violin plots that included MCI. We then performed linear regression analysis to evaluate whether the TRS is associated with the following $\mathrm{AD}$ biomarkers: (1) hippocampal volume and entorhinal cortical thickness measured from T1-weighted brain MRI scans using FreeSurfer version 5.1 (surfer.nmr.mgh.harvard.edu), ${ }^{24}$ (2) global cortical amyloid accumulation as mean standardized uptake values (SUVs) using preprocessed (coregistered, averaged, standardized image and voxel size, uniform resolution) $\left[{ }^{18} \mathrm{~F}\right]$ florbetapir PET scans with a whole cerebellum reference region, ${ }^{25}$ and (3) Alzheimer's Disease Assessment Scale Cognitive Subscale 13 (ADAS-cog13) ${ }^{26}$ Covariates included age and sex. Intracranial volumes (ICV) and MRI field strength were also used as additional covariates for hippocampal volume and entorhinal cortical thickness. Educational level was also used as an additional covariate for ADAS- $\operatorname{cog} 13$. ADAS- $\operatorname{cog} 13$ and amyloid PET data were not available in AddNeuroMed. In addition, we also performed logistic regression analysis to evaluate whether the TRS is significantly different between patients with $\mathrm{AD}$ with positive amyloid PET (SUV ratio $\geq 1.17$ ) and $\mathrm{CN}$ with negative amyloid PET (SUV ratio <1.17) in the ADNI.

Although we designated target genes as high expression and low expression based on the integration of GWAS summary statistics and the public blood eQTL database, expression levels of the target genes in the ADNI and AddNeuroMed may not be different between $\mathrm{AD}$ and $\mathrm{CN}$. Therefore, for target genes used to calculate the TRS, we performed logistic 
Table 1 Demographics of study samples

\begin{tabular}{|c|c|c|c|c|c|}
\hline Cohort & Diagnosis & $\mathbf{N}$ & Female, n (\%) & Age at blood sample collection, mean (SD) & RIN, mean (SD) \\
\hline \multirow[t]{3}{*}{ ADNI $(N=661)$} & $\mathrm{CN}$ & 213 & $107(50)$ & $76.4(6.4)$ & $6.91(0.51)$ \\
\hline & $\mathrm{MCl}$ & 345 & $144(42)$ & $73.2(7.9)$ & $6.98(0.55)$ \\
\hline & $A D$ & 103 & $38(37)$ & $77.6(7.8)$ & $6.98(0.64)$ \\
\hline \multirow[t]{3}{*}{ AddNeuroMed $(\mathrm{N}=674)$} & $\mathrm{CN}$ & 243 & $147(60)$ & $74.2(6.6)$ & $8.96(0.73)$ \\
\hline & $\mathrm{MCl}$ & 208 & $120(58)$ & $75.5(6.5)$ & $8.50(0.59)$ \\
\hline & $A D$ & 223 & $146(65)$ & 76.8 (6.8) & $8.43(0.64)$ \\
\hline
\end{tabular}

Abbreviations: $A D=$ Alzheimer disease; $A D N I=$ Alzheimer's Disease Neuroimaging Initiative; $C N=$ cognitively normal older adults; $\mathrm{MCI}=$ mild cognitive impairment; RIN = RNA integrity number.

The mean and SD of age at onset in patients with $A D$ in the ADNI were 75.5 and 7.83 , respectively.

The table was modified from a previous study. ${ }^{40}$

regression analysis of gene expression levels using the $\mathrm{AD}$ diagnosis group, with age and sex as independent variables and diagnosis as an outcome, to identify which genes are significantly upregulated or downregulated in $\mathrm{AD}$ compared with $\mathrm{CN}$. We also used a heatmap to visualize the expression pattern across the participants. In this study, we used $\mathrm{R}$ version 3.6.0 (R-project.org) for analysis unless otherwise specified. The study is rated Class III because of the case control design and the risk of spectrum bias.

\section{Standard protocol approvals, registrations, and patient consents}

Written informed consent was obtained at the time of enrollment and included permission for analysis and data sharing. The protocol and informed consent forms were approved by the Institutional Review Board at each participating site. ClinicalTrials. gov identifiers are NCT00106899, NCT01078636, and NCT01231971.

\section{Data availability}

Anonymized data used for this study are available from the corresponding authors on reasonable request.

\section{Results}

In this study, a total of 1,335 participants were included from 2 independent cohorts (661 from the ADNI and 674 from AddNeuroMed) (table 1). Using large-scale AD GWAS results and the public blood eQTL database, we selected candidate genes that are within $\pm 1 \mathrm{Mbp}$ of $\mathrm{AD}$-associated SNPs and have a direct impact on gene expression (table 2). Then, using COLOC and SMR (table 2), we identified target genes that have strong

Table 2 Candidate genes under control of AD-associated SNPs ( $\pm 1 \mathrm{Mbp})$ and target genes after applying COLOC and SMR

\begin{tabular}{|c|c|c|}
\hline $\begin{array}{l}\text { Criteria for selecting } \\
\text { AD-associated SNPs }\end{array}$ & $\begin{array}{l}\text { No. of } \\
\text { candidate } \\
\text { genes }\end{array}$ & Target genes identified using COLOC and SMR ${ }^{a}$ \\
\hline$p<5 \times 10^{-8 b}$ & 17 & $B 4 G A L T 3^{c}, B C K D K^{c}, C D 33, C R 1^{c}, E P H A 1, M S 4 A 2^{d}, M S 4 A 4 A, M S 4 A 6 A, P I L R A, S T A G 3^{c}$, and ZNF668 \\
\hline$p<1 \times 10^{-7}$ & 15 & $B 4 G A L T 3^{c}, C D 33, K L C 3^{d}, P I L R A, S T A G 3^{c}$, and TRAPPC6A \\
\hline$p<1 \times 10^{-6}$ & 18 & $B 4 G A L T 3^{\mathrm{c}}, C D 33, K L C 3^{\mathrm{d}}$, PILRA, RTN2 ${ }^{\mathrm{c}}$, STAG3 $^{\mathrm{c}}$, and TRAPPC6A \\
\hline$p<1 \times 10^{-5}$ & 24 & 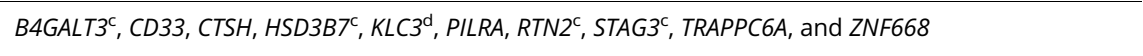 \\
\hline$p<1 \times 10^{-4}$ & 47 & 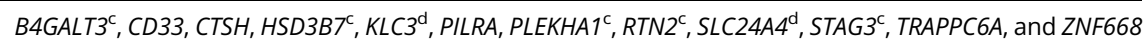 \\
\hline$p<1 \times 10^{-3}$ & 171 & 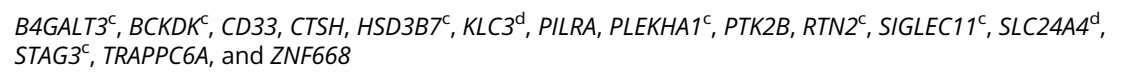 \\
\hline$p<1 \times 10^{-2}$ & 536 & 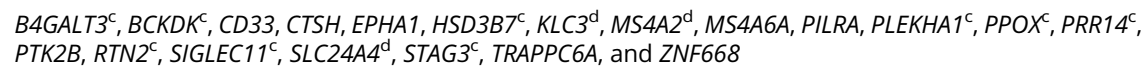 \\
\hline
\end{tabular}

Abbreviations: AD = Alzheimer disease; ADNI = Alzheimer's Disease Neuroimaging Initiative; SMR = summary data-based mendelian randomization; SNP = single nucleotide polymorphism.

The microarray gene expression data for MS4A2, SIGLEC11 and STAG3 were not available in ADNI. The microarray gene expression data for CR1, EPHA1, HSD3B7, KLC3, MS4A2, MS4A4A, PPOX, RTN2, SIGLEC11, SLC24A4, STAG3 and ZNF668 were not available in AddNeuroMed.

a Unless otherwise specified, genes were identified by both COLOC and SM.

b SNPs in strong linkage disequilibrium $\left(r^{2}>0.8\right)$ with the SNPs that had genome-wide significant associations $\left(p<5 \times 10^{-8}\right)$ were also included for analysis.

${ }^{c}$ These genes were identified by COLOC only.

d These genes were identified by SMR only. 
Table 3 Difference of the TRS between CN (N = 213) and AD ( $=103)$ according to various criteria for selecting AD-associated SNPs in ADNI

\begin{tabular}{|c|c|c|c|c|c|c|c|c|c|}
\hline \multirow{2}{*}{$\begin{array}{l}\text { Criteria for } \\
\text { selecting SNPs }\end{array}$} & \multicolumn{2}{|c|}{$\begin{array}{l}\text { TRS using all } \\
\text { candidate genes, } \\
\text { mean (SD) }\end{array}$} & \multirow{2}{*}{$\begin{array}{l}\text { OR of the TRS } \\
\text { ( } 95 \% \mathrm{Cl}, p \text { value) }\end{array}$} & \multicolumn{2}{|c|}{$\begin{array}{l}\text { TRS using target } \\
\text { genes from } \\
\text { COLOC, mean (SD) }\end{array}$} & \multirow{2}{*}{$\begin{array}{l}\text { OR of the TRS } \\
\text { ( } 95 \% \mathrm{Cl}, p \text { value) }\end{array}$} & \multicolumn{2}{|c|}{$\begin{array}{l}\text { TRS using target } \\
\text { genes from SMR, } \\
\text { mean (SD) }\end{array}$} & \multirow{2}{*}{$\begin{array}{l}\text { OR of the TRS } \\
\text { (95\% Cl, } p \text { value) }\end{array}$} \\
\hline & $\mathrm{CN}$ & $A D$ & & $\mathrm{CN}$ & $A D$ & & $\mathrm{CN}$ & $A D$ & \\
\hline$p<5 \times 10^{-8 a}$ & $\begin{array}{l}-0.477 \\
(5.05)\end{array}$ & $\begin{array}{l}1.10 \\
(4.13)\end{array}$ & $\begin{array}{l}1.06(1.01-1.13 \\
\left.3.02 \times 10^{-2}\right)\end{array}$ & $\begin{array}{l}-0.467 \\
(4.92)\end{array}$ & $\begin{array}{l}1.39 \\
(3.86)\end{array}$ & $\begin{array}{l}1.08(1.02-1.15 \\
\left.6.03 \times 10^{-3}\right)\end{array}$ & $\begin{array}{l}-0.238 \\
(3.56)\end{array}$ & $\begin{array}{l}0.807 \\
(2.92)\end{array}$ & $\begin{array}{l}1.08(1.00-1.17 \\
\left.5.01 \times 10^{-2}\right)\end{array}$ \\
\hline$p<1 \times 10^{-7}$ & $\begin{array}{l}-0.264 \\
(4.40)\end{array}$ & $\begin{array}{l}1.11 \\
(4.05)\end{array}$ & $\begin{array}{l}1.08(1.02-1.14 \\
\left.1.33 \times 10^{-2}\right)\end{array}$ & $\begin{array}{l}-0.209 \\
(2.69)\end{array}$ & $\begin{array}{l}0.881 \\
(2.33)\end{array}$ & $\begin{array}{l}1.18(1.07-1.31 \\
\left.1.19 \times 10^{-3}\right)\end{array}$ & $\begin{array}{l}-0.0973 \\
(2.39)\end{array}$ & $\begin{array}{l}0.809 \\
(2.23)\end{array}$ & $\begin{array}{l}1.18(1.06-1.33 \\
\left.2.58 \times 10^{-3}\right)\end{array}$ \\
\hline$p<1 \times 10^{-6}$ & $\begin{array}{l}-0.324 \\
(4.90)\end{array}$ & $\begin{array}{l}1.40 \\
(4.71)\end{array}$ & $\begin{array}{l}1.08(1.02-1.14 \\
\left.4.77 \times 10^{-3}\right)\end{array}$ & $\begin{array}{l}-0.122 \\
(2.58)\end{array}$ & $\begin{array}{l}0.771 \\
(2.35)\end{array}$ & $\begin{array}{l}1.15(1.05-1.28 \\
\left.5.20 \times 10^{-3}\right)\end{array}$ & $\begin{array}{l}-0.0973 \\
(2.39)\end{array}$ & $\begin{array}{l}0.809 \\
(2.23)\end{array}$ & $\begin{array}{l}1.18(1.06-1.33 \\
\left.2.58 \times 10^{-3}\right)\end{array}$ \\
\hline$p<1 \times 10^{-5}$ & $\begin{array}{l}-0.339 \\
(6.04)\end{array}$ & $\begin{array}{l}1.67 \\
(5.18)\end{array}$ & $\begin{array}{l}1.06(1.02-1.11 \\
\left.7.45 \times 10^{-3}\right)\end{array}$ & $\begin{array}{l}-0.140 \\
(3.23)\end{array}$ & $\begin{array}{l}1.25 \\
(2.86)\end{array}$ & $\begin{array}{l}1.14(1.05-1.24 \\
\left.1.44 \times 10^{-3}\right)\end{array}$ & $\begin{array}{l}-0.139 \\
(3.03)\end{array}$ & $\begin{array}{l}1.16 \\
(2.63)\end{array}$ & $\begin{array}{l}1.16(1.06-1.27 \\
\left.1.34 \times 10^{-3}\right)\end{array}$ \\
\hline$p<1 \times 10^{-4}$ & $\begin{array}{l}-0.644 \\
(7.80)\end{array}$ & $\begin{array}{l}1.64 \\
(6.21)\end{array}$ & $\begin{array}{l}1.04(1.00-1.07 \\
\left.3.31 \times 10^{-2}\right)\end{array}$ & $\begin{array}{l}-0.0544 \\
(3.00)\end{array}$ & $\begin{array}{l}1.11 \\
(2.78)\end{array}$ & $\begin{array}{l}1.14(1.05-1.24 \\
\left.3.28 \times 10^{-3}\right)\end{array}$ & $\begin{array}{l}-0.0961 \\
(2.75)\end{array}$ & $\begin{array}{l}1.04 \\
(2.46)\end{array}$ & $\begin{array}{l}1.16(1.06-1.28 \\
\left.2.20 \times 10^{-3}\right)\end{array}$ \\
\hline$p<1 \times 10^{-3}$ & $\begin{array}{l}-0.314 \\
(13.5)\end{array}$ & $\begin{array}{l}1.47 \\
(11.5)\end{array}$ & $\begin{array}{l}1.01(0.988-1.03 \\
\left.4.89 \times 10^{-1}\right)\end{array}$ & $\begin{array}{l}-0.228 \\
(3.91)\end{array}$ & $\begin{array}{l}1.54 \\
(3.39)\end{array}$ & $\begin{array}{l}1.13(1.05-1.21 \\
\left.7.03 \times 10^{-4}\right)\end{array}$ & $\begin{array}{l}-0.189 \\
(3.22)\end{array}$ & $\begin{array}{l}1.26 \\
(2.92)\end{array}$ & $\begin{array}{l}1.15(1.06-1.25 \\
\left.8.73 \times 10^{-4}\right)\end{array}$ \\
\hline$p<1 \times 10^{-2}$ & $\begin{array}{l}1.07 \\
(24.5)\end{array}$ & $\begin{array}{l}2.95 \\
(23.4)\end{array}$ & $\begin{array}{l}1.00(0.994-1.01 \\
\left.4.84 \times 10^{-1}\right)\end{array}$ & $\begin{array}{l}-0.282 \\
(5.38)\end{array}$ & $\begin{array}{l}1.92 \\
(4.73)\end{array}$ & $\begin{array}{l}1.08(1.03-1.14 \\
\left.2.88 \times 10^{-3}\right)\end{array}$ & $\begin{array}{l}-0.257 \\
(3.89)\end{array}$ & $\begin{array}{l}1.47 \\
(3.44)\end{array}$ & $\begin{array}{l}1.12(1.05-1.21 \\
\left.1.15 \times 10^{-3}\right)\end{array}$ \\
\hline
\end{tabular}

Abbreviations: $\mathrm{AD}=$ Alzheimer disease; $\mathrm{ADNI}=$ Alzheimer's Disease Neuroimaging Initiative; $\mathrm{Cl}=$ confidence interval; $\mathrm{CN}=\mathrm{cognitively} \mathrm{normal} \mathrm{older} \mathrm{adults;} \mathrm{OR}$ = odds ratio; SNP = single nucleotide polymorphism; TRS = transcriptional risk score.

ORs and 95\% Cls of the TRS were derived from the logistic regression analysis with adjustment of age and sex.

a SNPs in strong linkage disequilibrium $\left(r^{2}>0.8\right)$ with the SNPs that had genome-wide significant associations $\left(p<5 \times 10^{-8}\right)$ were also included for analysis.

evidence for colocalization of association signals. When genome-wide significant SNPs $\left(p<5 \times 10^{-8}\right)$ were selected to identify candidate $\mathrm{AD}$-associated genes, the TRS of the candidate genes without the colocalization step was significantly different between $\mathrm{AD}$ and $\mathrm{CN}$ in the $\mathrm{ADNI}$ (odds ratio [OR] 1.06, 95\% CI 1.01-1.13) (table 3). However, when the TRS was calculated only from target genes identified by COLOC, the diagnosis group difference of the TRS was slightly larger (OR 1.08, 95\% CI 1.02-1.15). As shown in table 3 and figure 1, when $\mathrm{AD}$-associated SNPs with $p<1 \times 10^{-7}$ were selected to identify candidate genes, the diagnosis group difference of the TRS for target genes identified by COLOC or SMR was the largest (OR 1.18, 95\% CI 1.07-1.31 for COLOC; OR 1.18, 95\% CI 1.06-1.33 for SMR) (table 3 and figure 1). The result remained significant when the TRS was compared between patients with $\mathrm{AD}$ with positive amyloid PET and $\mathrm{CN}$ with negative amyloid PET (OR 1.21, 95\% CI 1.07-1.39 for COLOC; OR 1.24, 95\% CI 1.08-1.43 for SMR). In AddNeuroMed, the TRS was also significantly different between $\mathrm{AD}$ and $\mathrm{CN}$ (table e-1, links.lww.com/NXG/A321). Furthermore, the diagnosis group difference of the TRS for target genes identified by COLOC or SMR was the largest (OR 1.20, 95\% CI 1.12-1.30 for COLOC; OR 1.23, 95\% CI 1.13-1.35 for SMR) after AD-associated SNPs were selected with $p<1 \times$ $10^{-7}$ or $1 \times 10^{-6}$ (figure 1 ).

The TRS of target genes identified by COLOC or SMR was associated with MRI-based imaging biomarkers (hippocampal volume and entorhinal cortical thickness), cortical amyloid accumulation and ADAS-cog13 in the ADNI (tables e- 2 to e-5; figures e-1 and e-2, links.lww.com/NXG/A321). In AddNeuroMed, the TRS of target genes identified by COLOC or SMR was also associated with entorhinal cortical thickness (figure e-1 and table e-6). There was no significant association between the TRS and the hippocampal volume in AddNeuroMed.

Among 6 target genes identified by COLOC and SMR from $\mathrm{AD}$-associated SNPs with $p<1 \times 10^{-7}, 2$ genes (CD33 and PILRA) and 4 genes (B4GALT3, KLC3, STAG3, and TRAPPC6A) were labeled as high expression and low expression, respectively. In the ADNI, expression levels of 2 genes (CD33 and PILRA) were significantly increased, whereas 1 gene (TRAPPC6A) was significantly decreased in $\mathrm{AD}$ compared with $\mathrm{CN}$, which was consistent with the prediction based on the integration of GWAS and the public blood eQTL database (figure 2, figure e-3 and table e-7, links.lww.com/NXG/A321). Expression levels of the remaining 3 genes in $\mathrm{ADNI}$ were not significantly different between $\mathrm{AD}$ and $\mathrm{CN}$. In AddNeuroMed, expression levels of 2 genes (CD33 and PILRA) were significantly increased, and 2 genes (B4GALT3 and TRAPPC6A) were significantly decreased in $\mathrm{AD}$ compared to $\mathrm{CN}$, as predicted by the GWAS and the eQTL database (figure 2, figure e-3 and table e-7). Expression levels of the remaining 2 genes in AddNeuroMed were not significantly different between $\mathrm{AD}$ and $\mathrm{CN}$. Thus, the diagnosis group difference and directionality of gene expression levels of CD33, PILRA, and TRAPPC6A that were identified in ADNI were replicated in AddNeuroMed. 
Figure 1 Violin plots for the TRS between $\mathrm{CN}, \mathrm{MCl}$, and $\mathrm{AD}$
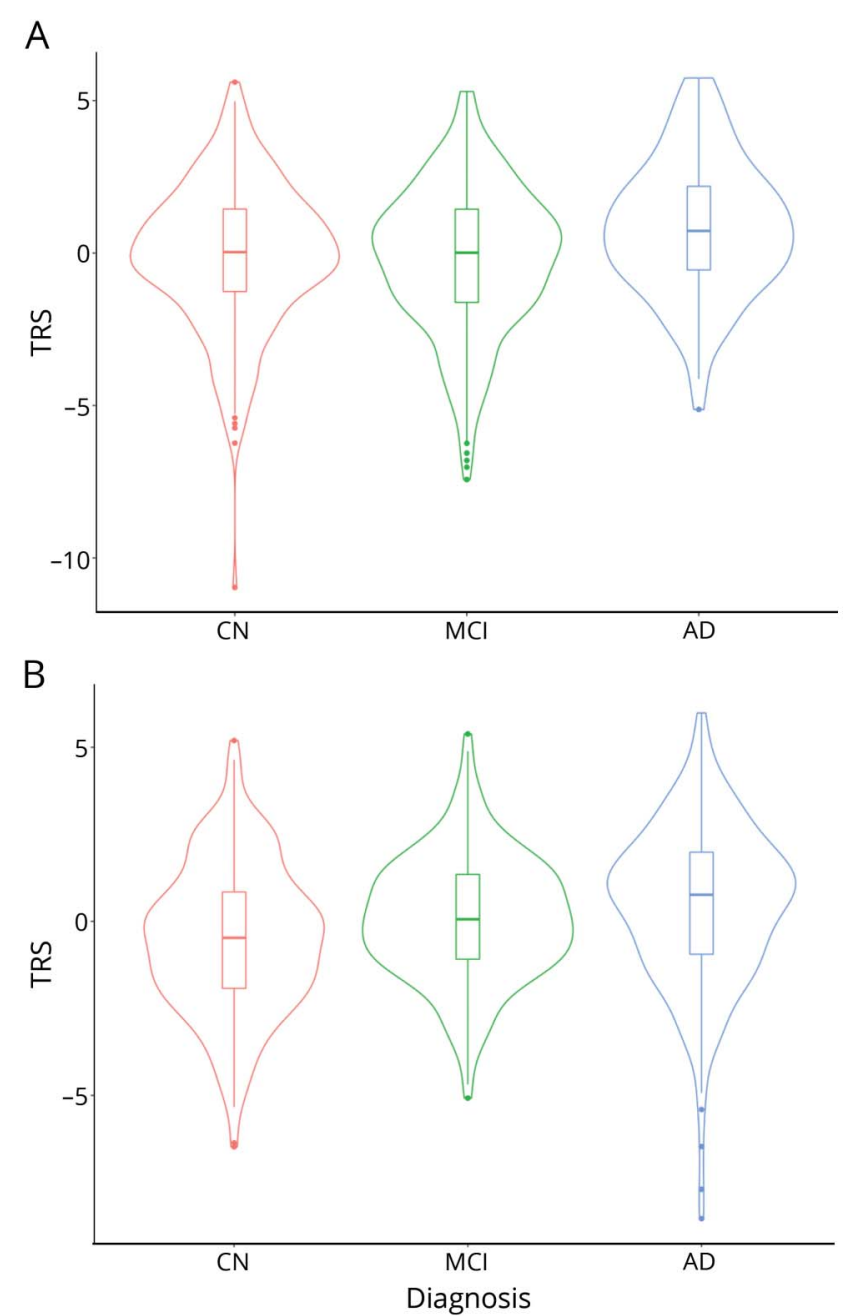

Target genes identified from SMR at $p$ value of AD-associated SNPs less than $1 \times 10^{-9}$ were used to calculate the TRS. The violin plot shows the probability density of the TRS data as well as median and interquartile ranges in ADN (A) and AddNeuroMed (B). AD = Alzheimer disease; $A D N I=$ Alzheimer's Disease Neuroimaging Initiative; $\mathrm{CN}=$ cognitively normal older adults; $\mathrm{MCl}=$ mild cognitive impairment; SMR = summary data-based mendelian randomization; TRS = transcriptional risk score.

\section{Discussion}

In this study, we selected candidate $\mathrm{AD}$-associated genes by integrating large-scale $\mathrm{AD}$ GWAS summary statistics with the public blood eQTL database. Candidate genes were prioritized using COLOC and SMR to identify the target genes. Then, the TRS was calculated using blood-based transcriptome profiles of the target genes from 2 independent cohorts (ADNI and AddNeuroMed). The TRS was not only significantly different between $\mathrm{AD}$ and $\mathrm{CN}$ but also significantly associated with entorhinal cortical thickness in both of the cohorts. When AD-associated SNPs were selected from GWAS summary statistics with $p$ values less than $1 \times 10^{-7}$, the TRS showed the largest associations with diagnosis and $\mathrm{AD}$ biomarkers in general. In addition, we found that expression levels of 2 genes (CD33 and PILRA) were significantly increased, and 1 gene
(TRAPPC6A) was significantly decreased in $\mathrm{AD}$ compared with $\mathrm{CN}$ in the ADNI and AddNeuroMed, which was consistent with the prediction based on the GWAS and the public blood eQTL database. The expression of these genes in peripheral blood may be associated with the corresponding $\mathrm{AD}$-associated SNPs and have an impact on the pathophysiology of $\mathrm{AD}$.

CD33 encodes a sialic acid-binding transmembrane glycoprotein expressed on the surface of immune cells ${ }^{27}$ and is one of the top-ranked $\mathrm{AD}$ risk genes identified by the GWAS. ${ }^{3}$ It contains immunoreceptor tyrosine-based inhibitory motifs (ITIMs) that inhibit cellular activity such as phagocytosis. ${ }^{27}$ As demonstrated in this study, the $\mathrm{C}$ (risk) allele of rs3865444 $\left(\mathrm{rs} 3865444^{\mathrm{C}}\right)$ is known to be associated with increased expression levels of $\mathrm{CD} 33$ on peripheral blood monocytes. ${ }^{28}$ Although overall phagocytic activity of peripheral monocytes is reported to increase in subjects with positive amyloid PET scans compared with subjects with negative amyloid PET scans, ${ }^{29}$ rs $3865444^{\mathrm{C}}$ was found to be associated with reduced uptake of $\beta$-amyloid $(A \beta)$ on peripheral blood monocytes. ${ }^{28}$ This suggests that increased expression levels of $C D 33$ by rs $3865444^{C}$ may interfere with peripheral uptake of $A \beta$, which could play a role in the pathogenesis of $\mathrm{AD}$.

PILRA encodes paired immunoglobulin-like type 2 receptor alpha that is a cell surface inhibitory receptor with ITIM on immune cells. ${ }^{30}$ The A (protective) allele of rs 1859788 $\left(\mathrm{rs} 1859788^{\mathrm{A}}\right)$ is a missense mutation that causes a conformational change of PILRA by a glycine-to-arginine substitution near the sialic acid-binding pocket and inhibits the binding of ligands to PILRA. ${ }^{31}$ One of the ligands for PILRA is glycoprotein $\mathrm{B}(\mathrm{gB})$ of herpes simplex virus 1 (HSV-1), which is important for HSV-1 to enter the cells. ${ }^{30}$ The transfected cells with rs $1859788^{\mathrm{A}}$ had reduced binding of PILRA with HSV-1 $\mathrm{gB}$ and decreased levels of HSV-1 infection. ${ }^{31}$ In addition to the conformational change of PILRA, our study suggests that $\mathrm{rs} 1859788^{\mathrm{A}}$ is associated with reduced expression of PILRA in blood. Considering that the HSV-1 infection causes the accumulation of $A \beta$ and phosphorylated tau, ${ }^{32}$ altered expression of PILRA by $\mathrm{rs} 1859788^{\mathrm{A}}$ may be protective for $\mathrm{AD}$ due to decreased reactivation of HSV-1.

TRAPPC6A encodes trafficking protein particle complex 6A. Although it is not clear how it affects the pathogenesis of $A D$, genetic variation of TRAPPC6A is reported to be associated with nonverbal reasoning. ${ }^{33}$

Given that we identified candidate and target genes from the public blood eQTL database and calculated the TRS using blood transcriptome data from the ADNI and AddNeuroMed cohorts, mechanisms that were identified in this study were observed in peripheral blood. Although $\mathrm{AD}$ is viewed primarily as a neurodegenerative CNS disease, many systemic manifestations have suggested that $\mathrm{AD}$ is a multifactorial disease that affects both the brain and the periphery. ${ }^{34}$ In general, the systemic manifestations parallel the progressive 


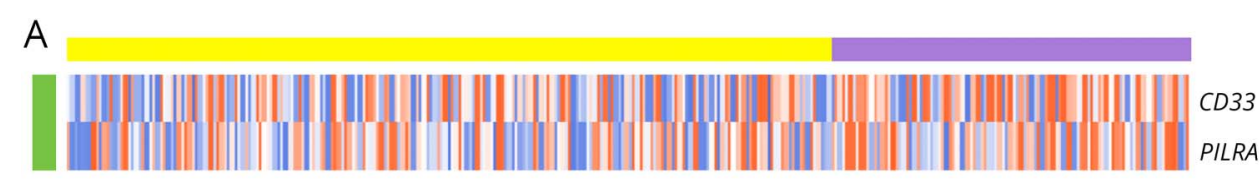

B

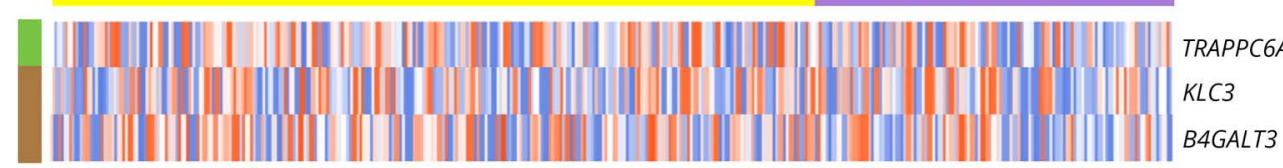

C

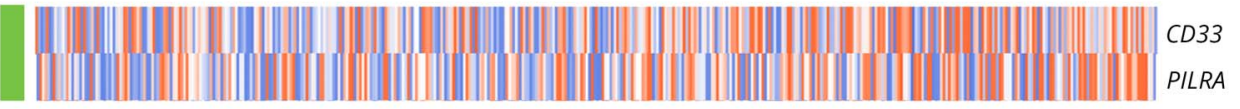

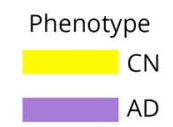

Consistent with the prediction

Significant

Not significant

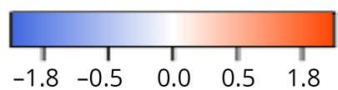

D

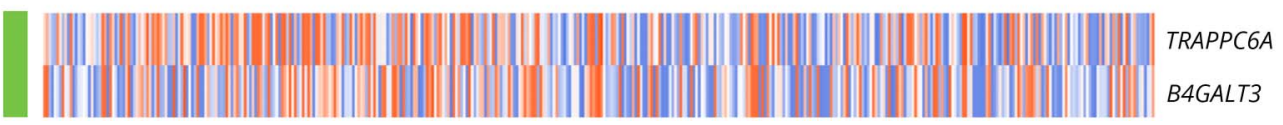

Two genes ( $C D 33$ and PILRA) that were predicted to have increased expression in patients with AD from the integration of GWAS summary statistics and eQTL data showed significantly increased expression in patients with AD in ADNI (A). Among 3 genes predicted to have decreased expression in patients with AD, 1 gene (TRAPPC6A) showed significantly decreased expression in patients with AD in ADNI (B). In AddNeuroMed, the expression level of two genes (CD33 and PILRA) was significantly increased in patients with $A D(C)$, whereas the expression level of two genes (B4GALT3 and TRAPPC6A) was significantly decreased in patients with $A D(D)$. The gene expression values were transformed into a normal distribution with mean 0 and variance 1 . $A D=A l z h e i m e r$ disease; $A D N I=$ Alzheimer's Disease Neuroimaging Initiative; CN = cognitively normal older adults; eQTL = expression quantitative trait locus; GWAS = genome-wide association study.

functional decline associated with neurodegeneration. ${ }^{34}$ However, some systemic manifestations are also observable before the presence of CNS symptoms of $\mathrm{AD} .^{35}$ Because blood interacts with all organs in the body, including the brain, blood-based profiles might provide an accessible and effective tool for evaluating the complex interplay between the brain and the periphery in the pathogenesis of $\mathrm{AD} .^{36}$

The present study has some limitations. First, we used the public blood eQTL database generated from $\mathrm{CN}$, not from patients with $\mathrm{AD}$. As the relationship between gene expression levels and SNPs may be different in normal subjects and patients with $\mathrm{AD}$, it would be better to use a blood eQTL database including patients with $\mathrm{AD}$. However, there is no public blood eQTL database generated from cohorts including patients with $\mathrm{AD}$. Further study using the eQTL database including patients with $\mathrm{AD}$ is needed to identify pathogenic genes more precisely. Second, the ADNI participants may not be representative of the general population of older adults. To generalize our findings, we need to validate our findings in larger community-based prospective cohort studies. Third, blood-based transcriptomic profiles could be influenced by confounding factors such as medication, as well as blood collection, processing, and storage procedures. ${ }^{36,37}$ The transcriptome samples in the ADNI and AddNeuroMed were collected, processed, and stored following the standard protocols to minimize these risks. Fourth, transcriptome profiling was performed on different microarray platforms in the ADNI and AddNeuroMed. Therefore, in this study, we did not perform a mega-analysis but calculated the TRS in the ADNI and AddNeuroMed separately. Finally, we analyzed cross-sectionally collected gene expression data. Our findings thus represent association not causality. Longitudinal studies are needed to understand the role of altered transcriptome profiles in the onset of $\mathrm{AD}$ as well as cause-and-effect relationships.

In conclusion, we selected genes to calculate the TRS by integrating $\mathrm{AD}$ GWAS summary statistics with the public blood eQTL database, and we demonstrated that the bloodbased TRS was significantly associated with $\mathrm{AD}$ biomarkers by using the transcriptomic database from the ADNI and AddNeuroMed cohorts. Looking toward the future, given the extensive omics data generated by various studies with better integrative approaches, it will likely become easier to determine the relation to relevant pathophysiologic mechanisms and discover novel biomarkers for clinical use. ${ }^{38}$ With more omics data and sophisticated integrative approaches for analysis, multilayer omics data are likely to become useful for predicting, diagnosing, and personalizing treatment for $\mathrm{AD} .^{39}$

\section{Acknowledgment}

The authors thank Dr. Urko M. Marigorta (CIC bioGUNE, Spain) and Dr. Claudia Giambartolomei (Instituto Italiano di Tecnologia, Italy) for their technical support and helpful comments. 


\section{Study funding}

This work was supported by the National Research Foundation of Korea grant funded by the Korean government (Ministry of Science and ICT) (No. 2020R1C1C1013718). Data collection and sharing for this project was funded by the Alzheimer's Disease Neuroimaging Initiative (NIH Grant U01 AG024904) and DOD ADNI (Department of Defense award number W81XWH-12-2-0012). The ADNI is funded by the National Institute on Aging, the National Institute of Biomedical Imaging and Bioengineering, and through generous contributions from the following: AbbVie, Alzheimer's Association, Alzheimer's Drug Discovery Foundation, Araclon Biotech, BioClinica, Inc., Biogen, Bristol-Myers Squibb Company, CereSpir, Inc., Cogstate, Eisai Inc., Elan Pharmaceuticals, Inc., Eli Lilly and Company, EuroImmun, F. Hoffmann-La Roche Ltd and its affiliated company Genentech, Inc., Fujirebio, GE Healthcare, IXICO Ltd., Janssen Alzheimer Immunotherapy Research \& Development, LLC., Johnson \& Johnson Pharmaceutical Research \& Development LLC., Lumosity, Lundbeck, Merck \& Co., Inc., Meso Scale Diagnostics, LLC., NeuroRx Research, Neurotrack Technologies, Novartis Pharmaceuticals Corporation, Pfizer Inc., Piramal Imaging, Servier, Takeda Pharmaceutical Company, and Transition Therapeutics. The Canadian Institutes of Health Research is providing funds to support ADNI clinical sites in Canada. Private sector contributions are facilitated by the Foundation for the NIH (fnih.org). The grantee organization is the Northern California Institute for Research and Education, and the study is coordinated by the Alzheimer's Therapeutic Research Institute at the University of Southern California. ADNI data are disseminated by the Laboratory for Neuro Imaging at the University of Southern California. The collection and analysis of AddNeuroMed samples was supported by InnoMed (Innovative Medicines in Europe), an Integrated Project funded by the European Union of the Sixth Framework program priority FP6-2004LIFESCIHEALTH-5, the Alzheimer's Research Trust, the John and Lucille van Geest Foundation and the NIHR Biomedical Research Centre for Mental Health at the South London and Maudsley NHS Foundation Trust and [Institute of Psychiatry] Kings College London. Additional support for data analysis was provided by NLM R01 LM012535, NIA R03 AG054936, NIA R01 AG19771, NIA P30 AG10133, NLM R01 LM011360, DOD W81XWH-14-2-0151, NIGMS P50GM115318, NCATS UL1 TR001108, NIA K01 AG049050, the Alzheimer's Association, the Indiana Clinical and Translational Science Institute, and the IU Health-IU School of Medicine Strategic Neuroscience Research Initiative.

\section{Disclosure}

The authors report no disclosures relevant to the manuscript. Go to Neurology.org/NG for full disclosures.

\section{Publication history}

Received by Neurology: Genetics March 24, 2020. Accepted in final form August 24, 2020.
Appendix 1 Authors

\begin{tabular}{|c|c|c|}
\hline Name & Location & Contribution \\
\hline $\begin{array}{l}\text { Young Ho } \\
\text { Park, MD, } \\
\text { PhD }\end{array}$ & $\begin{array}{l}\text { Seoul National University } \\
\text { Bundang Hospital, } \\
\text { Republic of Korea }\end{array}$ & $\begin{array}{l}\text { Designed and conceptualized } \\
\text { the study; analyzed the data; } \\
\text { interpreted the data; and } \\
\text { drafted the manuscript for } \\
\text { intellectual content }\end{array}$ \\
\hline $\begin{array}{l}\text { Angela } \\
\text { Hodges, } \\
\text { PhD }\end{array}$ & $\begin{array}{l}\text { King's College London, } \\
\text { United Kingdom }\end{array}$ & $\begin{array}{l}\text { Major role in the acquisition of } \\
\text { data and revised the } \\
\text { manuscript for intellectual } \\
\text { content }\end{array}$ \\
\hline $\begin{array}{l}\text { Andrew } \\
\text { Simmons, } \\
\text { PhD }\end{array}$ & $\begin{array}{l}\text { King's College London, } \\
\text { United Kingdom }\end{array}$ & $\begin{array}{l}\text { Major role in the acquisition of } \\
\text { data }\end{array}$ \\
\hline $\begin{array}{l}\text { Simon } \\
\text { Lovestone, } \\
\text { PhD }\end{array}$ & $\begin{array}{l}\text { King's College London, } \\
\text { United Kingdom }\end{array}$ & $\begin{array}{l}\text { Major role in the acquisition of } \\
\text { data }\end{array}$ \\
\hline $\begin{array}{l}\text { Michael W. } \\
\text { Weiner, } \\
\text { MD }\end{array}$ & $\begin{array}{l}\text { University of California- } \\
\text { San Francisco }\end{array}$ & $\begin{array}{l}\text { Major role in the acquisition of } \\
\text { data }\end{array}$ \\
\hline $\begin{array}{l}\text { SangYun } \\
\text { Kim, MD, } \\
\text { PhD }\end{array}$ & $\begin{array}{l}\text { Seoul National University } \\
\text { Bundang Hospital, } \\
\text { Republic of Korea }\end{array}$ & $\begin{array}{l}\text { Revised the manuscript for } \\
\text { intellectual content }\end{array}$ \\
\hline $\begin{array}{l}\text { Andrew J. } \\
\text { Saykin, } \\
\text { PsyD }\end{array}$ & $\begin{array}{l}\text { Indiana University, } \\
\text { Indianapolis }\end{array}$ & $\begin{array}{l}\text { Major role in the acquisition of } \\
\text { data; interpreted the data; } \\
\text { and revised the manuscript } \\
\text { for intellectual content }\end{array}$ \\
\hline $\begin{array}{l}\text { Kwangsik } \\
\text { Nho, PhD }\end{array}$ & $\begin{array}{l}\text { Indiana University, } \\
\text { Indianapolis }\end{array}$ & $\begin{array}{l}\text { Designed and conceptualized } \\
\text { the study; interpreted the } \\
\text { data; and revised the } \\
\text { manuscript for intellectual } \\
\text { content }\end{array}$ \\
\hline
\end{tabular}

Appendix 2 Coinvestigators

\begin{tabular}{|c|c|c|}
\hline Name & Location & Contribution \\
\hline $\begin{array}{l}\text { Michael W. } \\
\text { Weiner, MD }\end{array}$ & UC San Francisco & $\begin{array}{l}\text { Principal investigator/initial } \\
\text { concept planning and } \\
\text { development/early } \\
\text { project proposal } \\
\text { development }\end{array}$ \\
\hline Paul Aisen, MD & $\begin{array}{l}\text { University of } \\
\text { Southern California }\end{array}$ & $\begin{array}{l}\text { ATRI PI and Director of } \\
\text { Coordinating Center } \\
\text { Clinical Core for intellectual } \\
\text { content/Clinical Core } \\
\text { Leaders }\end{array}$ \\
\hline $\begin{array}{l}\text { Ronald } \\
\text { Petersen, MD, } \\
\text { PhD }\end{array}$ & $\begin{array}{l}\text { Mayo Clinic, } \\
\text { Rochester }\end{array}$ & $\begin{array}{l}\text { Member of Executive } \\
\text { Committee/Clinical Core } \\
\text { Leaders }\end{array}$ \\
\hline $\begin{array}{l}\text { Clifford R. Jack, } \\
\text { Jr., MD }\end{array}$ & $\begin{array}{l}\text { Mayo Clinic, } \\
\text { Rochester }\end{array}$ & $\begin{array}{l}\text { Member of Executive } \\
\text { Committee/MRI Core } \\
\text { Leaders and Key } \\
\text { Personnel }\end{array}$ \\
\hline $\begin{array}{l}\text { William Jagust, } \\
\text { MD }\end{array}$ & UC Berkeley & $\begin{array}{l}\text { Member of Executive } \\
\text { Committee/PET Core } \\
\text { Leaders and Key } \\
\text { Personnel }\end{array}$ \\
\hline $\begin{array}{l}\text { John Q. } \\
\text { Trojanowki, } \\
\text { MD, PhD }\end{array}$ & $\begin{array}{l}\text { University of } \\
\text { Pennsylvania }\end{array}$ & $\begin{array}{l}\text { Member of Executive } \\
\text { Committee/Biomarkers } \\
\text { Core Leaders and Key } \\
\text { Personnel }\end{array}$ \\
\hline
\end{tabular}


Appendix 2 (continued)

\begin{tabular}{|c|c|c|}
\hline Name & Location & Contribution \\
\hline $\begin{array}{l}\text { Arthur W. Toga, } \\
\text { PhD }\end{array}$ & $\begin{array}{l}\text { University of } \\
\text { Southern California }\end{array}$ & $\begin{array}{l}\text { Member of Executive } \\
\text { Committee/Informatics } \\
\text { Core Leaders and Key } \\
\text { Personnel }\end{array}$ \\
\hline $\begin{array}{l}\text { Laurel Beckett, } \\
\text { PhD }\end{array}$ & UC Davis & $\begin{array}{l}\text { Member of Executive } \\
\text { Committee }\end{array}$ \\
\hline $\begin{array}{l}\text { Robert C. Green, } \\
\text { MD, MPH }\end{array}$ & $\begin{array}{l}\text { Brigham and } \\
\text { Women's Hospital/ } \\
\text { Harvard Medical } \\
\text { School }\end{array}$ & $\begin{array}{l}\text { Member of Executive } \\
\text { Committee/Member of Data } \\
\text { and Publications Committee }\end{array}$ \\
\hline $\begin{array}{l}\text { Andrew J. } \\
\text { Saykin, PsyD }\end{array}$ & Indiana University & $\begin{array}{l}\text { Member of Executive } \\
\text { Committee/Genetics Core } \\
\text { Leaders and Key Personnel }\end{array}$ \\
\hline John Morris, MD & $\begin{array}{l}\text { Washington } \\
\text { University St. Louis }\end{array}$ & $\begin{array}{l}\text { Member of Executive } \\
\text { Committee/Neuropathology } \\
\text { Core Leaders }\end{array}$ \\
\hline Leslie M. Shaw & $\begin{array}{l}\text { University of } \\
\text { Pennsylvania }\end{array}$ & $\begin{array}{l}\text { Member of Executive } \\
\text { Committee/Biomarkers } \\
\text { Core Leaders and Key } \\
\text { Personnel }\end{array}$ \\
\hline $\begin{array}{l}\text { Zaven } \\
\text { Khachaturian, } \\
\text { PhD }\end{array}$ & $\begin{array}{l}\text { Prevent Alzheimer's } \\
\text { Disease } 2020\end{array}$ & $\begin{array}{l}\text { Member of ADNI External } \\
\text { Advisory Board/Initial } \\
\text { Concept Planning and } \\
\text { Development/Early Project } \\
\text { Proposal Development }\end{array}$ \\
\hline $\begin{array}{l}\text { Greg Sorensen, } \\
\text { MD }\end{array}$ & Siemens & $\begin{array}{l}\text { Member of ADNI External } \\
\text { Advisory Board }\end{array}$ \\
\hline $\begin{array}{l}\text { Maria Carrillo, } \\
\text { PhD }\end{array}$ & $\begin{array}{l}\text { Alzheimer's } \\
\text { Association }\end{array}$ & $\begin{array}{l}\text { Member of ADNI External } \\
\text { Advisory Board }\end{array}$ \\
\hline Lew Kuller, MD & $\begin{array}{l}\text { University of } \\
\text { Pittsburgh }\end{array}$ & $\begin{array}{l}\text { Member of ADNI External } \\
\text { Advisory Board }\end{array}$ \\
\hline $\begin{array}{l}\text { Marc Raichle, } \\
\text { MD }\end{array}$ & $\begin{array}{l}\text { Washington } \\
\text { University St. Louis }\end{array}$ & $\begin{array}{l}\text { Member of ADNI External } \\
\text { Advisory Board }\end{array}$ \\
\hline Steven Paul, MD & Cornell University & $\begin{array}{l}\text { Member of ADNI External } \\
\text { Advisory Board/Early Project } \\
\text { Proposal Development }\end{array}$ \\
\hline $\begin{array}{l}\text { Peter Davies, } \\
\text { MD }\end{array}$ & $\begin{array}{l}\text { Albert Einstein } \\
\text { College of Medicine } \\
\text { of Yeshiva University }\end{array}$ & $\begin{array}{l}\text { Member of ADNI External } \\
\text { Advisory Board }\end{array}$ \\
\hline $\begin{array}{l}\text { Howard Fillit, } \\
\text { MD }\end{array}$ & $\begin{array}{l}\text { AD Drug Discovery } \\
\text { Foundation }\end{array}$ & $\begin{array}{l}\text { Member of ADNI External } \\
\text { Advisory Board }\end{array}$ \\
\hline Franz Hefti, PhD & $\begin{array}{l}\text { Acumen } \\
\text { Pharmaceuticals }\end{array}$ & $\begin{array}{l}\text { Member of ADNI External } \\
\text { Advisory Board }\end{array}$ \\
\hline $\begin{array}{l}\text { David } \\
\text { Holtzman, MD }\end{array}$ & $\begin{array}{l}\text { Washington } \\
\text { University St. Louis }\end{array}$ & $\begin{array}{l}\text { Member of ADNI External } \\
\text { Advisory Board }\end{array}$ \\
\hline $\begin{array}{l}\text { M. Marcel } \\
\text { Mesulam, MD }\end{array}$ & $\begin{array}{l}\text { Northwestern } \\
\text { University }\end{array}$ & $\begin{array}{l}\text { Member of ADNI External } \\
\text { Advisory Board }\end{array}$ \\
\hline $\begin{array}{l}\text { William Potter, } \\
\text { MD }\end{array}$ & $\begin{array}{l}\text { National Institute of } \\
\text { Mental Health }\end{array}$ & $\begin{array}{l}\text { Member of ADNI External } \\
\text { Advisory Board/Early Project } \\
\text { Proposal Development }\end{array}$ \\
\hline $\begin{array}{l}\text { Peter Snyder, } \\
\text { PhD }\end{array}$ & Brown University & $\begin{array}{l}\text { Member of ADNI External } \\
\text { Advisory Board/Early Project } \\
\text { Proposal Development }\end{array}$ \\
\hline $\begin{array}{l}\text { James Hendrix, } \\
\text { PhD }\end{array}$ & $\begin{array}{l}\text { Alzheimer's } \\
\text { Association }\end{array}$ & $\begin{array}{l}\text { Member of ADNI } 3 \text { Private } \\
\text { Partner Scientific Board }\end{array}$ \\
\hline
\end{tabular}

Appendix 2 (continued)

\begin{tabular}{|c|c|c|}
\hline Name & Location & Contribution \\
\hline $\begin{array}{l}\text { Aparna } \\
\text { Vasanthakumar }\end{array}$ & AbbVie & $\begin{array}{l}\text { Member of ADNI } 3 \text { Private } \\
\text { Partner Scientific Board }\end{array}$ \\
\hline $\begin{array}{l}\text { Tom Montine, } \\
\text { MD, PhD }\end{array}$ & $\begin{array}{l}\text { University of } \\
\text { Washington }\end{array}$ & $\begin{array}{l}\text { Member of Resource } \\
\text { Allocation Review } \\
\text { Committee }\end{array}$ \\
\hline $\begin{array}{l}\text { Michael Rafii, } \\
\text { MD, PhD }\end{array}$ & $\begin{array}{l}\text { University of } \\
\text { Southern California }\end{array}$ & $\begin{array}{l}\text { Clinical informatics, } \\
\text { operations, and regulatory } \\
\text { affairs }\end{array}$ \\
\hline $\begin{array}{l}\text { Tiffany Chow, } \\
\text { MD }\end{array}$ & $\begin{array}{l}\text { University of } \\
\text { Southern California }\end{array}$ & $\begin{array}{l}\text { Clinical informatics, } \\
\text { operations, and regulatory } \\
\text { affairs }\end{array}$ \\
\hline $\begin{array}{l}\text { Rema Raman, } \\
\text { PhD }\end{array}$ & $\begin{array}{l}\text { University of } \\
\text { Southern California }\end{array}$ & $\begin{array}{l}\text { Clinical informatics, } \\
\text { operations, and regulatory } \\
\text { affairs }\end{array}$ \\
\hline $\begin{array}{l}\text { Gustavo } \\
\text { Jimenez, MBS }\end{array}$ & $\begin{array}{l}\text { University of } \\
\text { Southern California }\end{array}$ & $\begin{array}{l}\text { Clinical informatics, } \\
\text { operations, and regulatory } \\
\text { affairs }\end{array}$ \\
\hline $\begin{array}{l}\text { Michael } \\
\text { Donohue, PhD }\end{array}$ & $\begin{array}{l}\text { University of } \\
\text { Southern California }\end{array}$ & $\begin{array}{l}\text { Clinical informatics, } \\
\text { operations, and regulatory } \\
\text { affairs }\end{array}$ \\
\hline $\begin{array}{l}\text { Devon Gessert, } \\
\text { BS }\end{array}$ & $\begin{array}{l}\text { University of } \\
\text { Southern California }\end{array}$ & $\begin{array}{l}\text { Clinical informatics, } \\
\text { operations, and regulatory } \\
\text { affairs }\end{array}$ \\
\hline $\begin{array}{l}\text { Kelly Harless, } \\
\text { BA }\end{array}$ & $\begin{array}{l}\text { University of } \\
\text { Southern California }\end{array}$ & $\begin{array}{l}\text { Clinical informatics, } \\
\text { operations, and regulatory } \\
\text { affairs }\end{array}$ \\
\hline $\begin{array}{l}\text { Jennifer Salazar, } \\
\text { MBS }\end{array}$ & $\begin{array}{l}\text { University of } \\
\text { Southern California }\end{array}$ & $\begin{array}{l}\text { Clinical informatics, } \\
\text { operations, and regulatory } \\
\text { affairs }\end{array}$ \\
\hline $\begin{array}{l}\text { Yuliana } \\
\text { Cabrera, BS }\end{array}$ & $\begin{array}{l}\text { University of } \\
\text { Southern California }\end{array}$ & $\begin{array}{l}\text { Clinical informatics, } \\
\text { operations, and regulatory } \\
\text { affairs }\end{array}$ \\
\hline $\begin{array}{l}\text { Sarah Walter, } \\
\text { MSc }\end{array}$ & $\begin{array}{l}\text { University of } \\
\text { Southern California }\end{array}$ & $\begin{array}{l}\text { Clinical informatics, } \\
\text { operations, and regulatory } \\
\text { affairs }\end{array}$ \\
\hline $\begin{array}{l}\text { Lindsey } \\
\text { Hergesheimer, } \\
\text { BS }\end{array}$ & $\begin{array}{l}\text { University of } \\
\text { Southern California }\end{array}$ & $\begin{array}{l}\text { Clinical informatics, } \\
\text { operations, and regulatory } \\
\text { affairs }\end{array}$ \\
\hline $\begin{array}{l}\text { Laurel Beckett, } \\
\text { PhD }\end{array}$ & UC Davis & $\begin{array}{l}\text { Biostatistics Core Leaders } \\
\text { and Key Personnel }\end{array}$ \\
\hline $\begin{array}{l}\text { Danielle } \\
\text { Harvey, PhD }\end{array}$ & UC Davis & $\begin{array}{l}\text { Biostatistics Core Leaders } \\
\text { and Key Personnel }\end{array}$ \\
\hline $\begin{array}{l}\text { Michael } \\
\text { Donohue, PhD }\end{array}$ & UC San Diego & $\begin{array}{l}\text { Biostatistics Core Leaders } \\
\text { and Key Personnel }\end{array}$ \\
\hline $\begin{array}{l}\text { Matthew } \\
\text { Bernstein, PhD }\end{array}$ & $\begin{array}{l}\text { Mayo Clinic, } \\
\text { Rochester }\end{array}$ & $\begin{array}{l}\text { MRI Core Leaders and Key } \\
\text { Personnel }\end{array}$ \\
\hline Nick Fox, MD & University of London & $\begin{array}{l}\text { MRI Core Leaders and Key } \\
\text { Personnel }\end{array}$ \\
\hline $\begin{array}{l}\text { Paul Thompson, } \\
\text { PhD }\end{array}$ & $\begin{array}{l}\text { UCLA School of } \\
\text { Medicine }\end{array}$ & $\begin{array}{l}\text { MRI Core Leaders and Key } \\
\text { Personnel }\end{array}$ \\
\hline $\begin{array}{l}\text { Norbert Schuff, } \\
\text { PhD }\end{array}$ & UC San Francisco & $\begin{array}{l}\text { MRI Core Leaders and Key } \\
\text { Personnel }\end{array}$ \\
\hline $\begin{array}{l}\text { Charles DeCArli, } \\
\text { MD }\end{array}$ & UC Davis & $\begin{array}{l}\text { MRI Core Leaders and Key } \\
\text { Personnel }\end{array}$ \\
\hline
\end{tabular}

Continued 
Appendix 2 (continued)

\begin{tabular}{|c|c|c|}
\hline Name & Location & Contribution \\
\hline $\begin{array}{l}\text { Bret Borowski, } \\
\text { RT }\end{array}$ & $\begin{array}{l}\text { Mayo Clinic, } \\
\text { Rochester }\end{array}$ & $\begin{array}{l}\text { MRI Core Leaders and Key } \\
\text { Personnel }\end{array}$ \\
\hline Jeff Gunter, PhD & $\begin{array}{l}\text { Mayo Clinic, } \\
\text { Rochester }\end{array}$ & $\begin{array}{l}\text { MRI Core Leaders and Key } \\
\text { Personnel }\end{array}$ \\
\hline $\begin{array}{l}\text { Matt Senjem, } \\
\text { MS }\end{array}$ & $\begin{array}{l}\text { Mayo Clinic, } \\
\text { Rochester }\end{array}$ & $\begin{array}{l}\text { MRI Core Leaders and Key } \\
\text { Personnel }\end{array}$ \\
\hline $\begin{array}{l}\text { Prashanthi } \\
\text { Vemuri, PhD }\end{array}$ & $\begin{array}{l}\text { Mayo Clinic, } \\
\text { Rochester }\end{array}$ & $\begin{array}{l}\text { MRI Core Leaders and Key } \\
\text { Personnel }\end{array}$ \\
\hline David Jones, MD & $\begin{array}{l}\text { Mayo Clinic, } \\
\text { Rochester }\end{array}$ & $\begin{array}{l}\text { MRI Core Leaders and Key } \\
\text { Personnel }\end{array}$ \\
\hline Kejal Kantarci & $\begin{array}{l}\text { Mayo Clinic, } \\
\text { Rochester }\end{array}$ & $\begin{array}{l}\text { MRI Core Leaders and Key } \\
\text { Personnel }\end{array}$ \\
\hline Chad Ward & $\begin{array}{l}\text { Mayo Clinic, } \\
\text { Rochester }\end{array}$ & $\begin{array}{l}\text { MRI Core Leaders and Key } \\
\text { Personnel }\end{array}$ \\
\hline $\begin{array}{l}\text { Robert A. } \\
\text { Koeppe, PhD }\end{array}$ & $\begin{array}{l}\text { University of } \\
\text { Michigan }\end{array}$ & $\begin{array}{l}\text { MRI Core Leaders and Key } \\
\text { Personnel }\end{array}$ \\
\hline $\begin{array}{l}\text { Norm Foster, } \\
\text { MD }\end{array}$ & University of Utah & $\begin{array}{l}\text { MRI Core Leaders and Key } \\
\text { Personnel }\end{array}$ \\
\hline $\begin{array}{l}\text { Eric M. Reiman, } \\
\text { MD }\end{array}$ & $\begin{array}{l}\text { Banner Alzheimer's } \\
\text { Institute }\end{array}$ & $\begin{array}{l}\text { PET Core Leaders and Key } \\
\text { Personnel }\end{array}$ \\
\hline $\begin{array}{l}\text { Kewei Chen, } \\
\text { PhD }\end{array}$ & $\begin{array}{l}\text { Banner Alzheimer's } \\
\text { Institute }\end{array}$ & $\begin{array}{l}\text { PET Core Leaders and Key } \\
\text { Personnel }\end{array}$ \\
\hline $\begin{array}{l}\text { Chet Mathis, } \\
\text { MD }\end{array}$ & $\begin{array}{l}\text { University of } \\
\text { Pittsburgh }\end{array}$ & $\begin{array}{l}\text { PET Core Leaders and Key } \\
\text { Personnel }\end{array}$ \\
\hline $\begin{array}{l}\text { Susan Landau, } \\
\text { PhD }\end{array}$ & UC Berkeley & $\begin{array}{l}\text { PET Core Leaders and Key } \\
\text { Personnel }\end{array}$ \\
\hline $\begin{array}{l}\text { Nigel J. Cairns, } \\
\text { PhD, FRCPath }\end{array}$ & $\begin{array}{l}\text { Washington } \\
\text { University St. Louis }\end{array}$ & $\begin{array}{l}\text { Neuropathology Core } \\
\text { Leaders }\end{array}$ \\
\hline $\begin{array}{l}\text { Erin Franklin, } \\
\text { MS, CCRP }\end{array}$ & $\begin{array}{l}\text { Washington } \\
\text { University St. Louis }\end{array}$ & $\begin{array}{l}\text { Neuropathology Core } \\
\text { Leaders }\end{array}$ \\
\hline $\begin{array}{l}\text { Virginia Lee, } \\
\text { PhD, MBA }\end{array}$ & $\begin{array}{l}\text { University of } \\
\text { Pennsylvania }\end{array}$ & $\begin{array}{l}\text { Biomarkers Core Leaders } \\
\text { and Key Personnel }\end{array}$ \\
\hline $\begin{array}{l}\text { Magdalena } \\
\text { Korecka, } \\
\text { PhD }\end{array}$ & $\begin{array}{l}\text { University of } \\
\text { Pennsylvania }\end{array}$ & $\begin{array}{l}\text { Biomarkers Core Leaders } \\
\text { and Key Personnel }\end{array}$ \\
\hline $\begin{array}{l}\text { Michal Figurski, } \\
\text { PhD }\end{array}$ & $\begin{array}{l}\text { University of } \\
\text { Pennsylvania }\end{array}$ & $\begin{array}{l}\text { Biomarkers Core Leaders } \\
\text { and Key Personnel }\end{array}$ \\
\hline Karen Crawford & $\begin{array}{l}\text { University of } \\
\text { Southern California }\end{array}$ & $\begin{array}{l}\text { Biomarkers Core Leaders } \\
\text { and Key Personnel }\end{array}$ \\
\hline Scott Neu, PhD & $\begin{array}{l}\text { University of } \\
\text { Southern California }\end{array}$ & $\begin{array}{l}\text { Biomarkers Core Leaders } \\
\text { and Key Personnel }\end{array}$ \\
\hline $\begin{array}{l}\text { Tatiana M. } \\
\text { Foroud, } \\
\text { PhD }\end{array}$ & Indiana University & $\begin{array}{l}\text { Genetics Core Leaders and } \\
\text { Key Personnel }\end{array}$ \\
\hline $\begin{array}{l}\text { Steven Potkin, } \\
\text { MD }\end{array}$ & UC Irvine & $\begin{array}{l}\text { Genetics Core Leaders and } \\
\text { Key Personnel }\end{array}$ \\
\hline Li Shen, PhD & Indiana University & $\begin{array}{l}\text { Genetics Core Leaders and } \\
\text { Key Personnel }\end{array}$ \\
\hline $\begin{array}{l}\text { Kelley Faber, } \\
\text { MS, CCRC }\end{array}$ & Indiana University & $\begin{array}{l}\text { Genetics Core Leaders and } \\
\text { Key Personnel }\end{array}$ \\
\hline $\begin{array}{l}\text { Sungeun Kim, } \\
\text { PhD }\end{array}$ & Indiana University & $\begin{array}{l}\text { Genetics Core Leaders and } \\
\text { Key Personnel }\end{array}$ \\
\hline
\end{tabular}

Appendix 2 (continued)

\begin{tabular}{lll}
\hline Name & Location & Contribution \\
\hline $\begin{array}{l}\text { Kwangsik Nho, } \\
\text { PhD }\end{array}$ & Indiana University & $\begin{array}{l}\text { Genetics Core Leaders and } \\
\text { Key Personnel }\end{array}$ \\
\hline $\begin{array}{l}\text { Marilyn Albert, } \\
\text { PhD }\end{array}$ & $\begin{array}{l}\text { Johns Hopkins } \\
\text { University }\end{array}$ & $\begin{array}{l}\text { Early Project Proposal } \\
\text { Development }\end{array}$ \\
\hline $\begin{array}{l}\text { Richard Frank, } \\
\text { MD, PhD }\end{array}$ & $\begin{array}{l}\text { Richard Frank } \\
\text { Consulting }\end{array}$ & $\begin{array}{l}\text { Early Project Proposal } \\
\text { Development }\end{array}$ \\
\hline John Hsiao, MD & $\begin{array}{l}\text { National Institute on } \\
\text { Aging }\end{array}$ & NIA \\
\hline
\end{tabular}

\section{References}

1. Cuyvers E, Sleegers K. Genetic variations underlying Alzheimer's disease: evidence from genome-wide association studies and beyond. Lancet Neurol 2016;15:857-868.

2. van Duijn CM, Clayton D, Chandra V, et al. Familial aggregation of Alzheimer's disease and related disorders: a collaborative re-analysis of case-control studies. Int J Epidemiol 1991;20:S13-S20.

3. Jansen IE, Savage JE, Watanabe K, et al. Genome-wide meta-analysis identifies new loci and functional pathways influencing Alzheimer's disease risk. Nat Genet 2019;51: 404-413.

4. Kunkle BW, Grenier-Boley B, Sims R, et al. Genetic meta-analysis of diagnosed Alzheimer's disease identifies new risk loci and implicates $A \beta$, tau, immunity and lipid processing. Nat Genet 2019;51:414-430.

5. Nicolae DL, Gamazon E, Zhang W, Duan S, Dolan ME. Trait-associated SNPs are more likely to be eQTLs: annotation to enhance discovery from GWAS. PLoS Genet 2010;6:e1000888.

6. Marigorta UM, Denson LA, Hyams JS, et al. Transcriptional risk scores link GWAS to eQTLs and predict complications in Crohn's disease. Nat Genet 2017;49:1517-1521.

7. Aisen PS, Petersen RC, Donohue M, Weiner MW. Alzheimer's Disease Beuroimaging Initiative 2 clinical core: progress and plans. Alzheimers Dement 2015;11:734-739.

8. Lovestone S, Francis P, Kloszewska I, et al. AddNeuroMed: the European collaboration for the discovery of novel biomarkers for Alzheimer's disease. Ann NY Acad Sci 2009;1180:36-46.

9. McKhann G, Drachman D, Folstein M, Katzman R, Price D, Stadlan EM. Clinical diagnosis of Alzheimer' disease: report of the NINCDS-ADRDA Work Group under the auspices of Department of Health and Human Services Task Force on Alzheimer' disease. Neurology 1984;34:939-944.

10. Saykin AJ, Shen L, Yao X, et al. Genetic studies of quantitative MCI and AD phenotypes in ADNI: progress, opportunities, and plans. Alzheimers Dement 2015;11: 792-814.

11. Simmons A, Breen G, Pedroso I, et al. Genome-wide association with MRI atrophy measures as a quantitative trait locus for Alzheimer's disease. Mol Psychiatry 2011;16: $1130-1138$.

12. Purcell S, Neale B, Todd-Brown K, et al. PLINK: a tool set for whole-genome association and population-based linkage analyses. Am J Hum Genet 2007;81: 559-575.

13. Lee Y, Han S, Kim D, et al. Genetic variation affecting exon skipping contributes to brain structural atrophy in Alzheimer's disease. AMIA Jt Summits Transl Sci Proc 2018;2017:124-131.

14. Price AL, Patterson NJ, Plenge RM, Weinblatt ME, Shadick NA, Reich D. Principal components analysis corrects for stratification in genome-wide association studies. Nat Genet 2006;38:904-909.

15. Thorisson GA, Smith AV, Krishnan L, Stein LD. The international HapMap project web site. Genome Res 2005;15:1592-1593.

16. Li Y, Willer CJ, Ding J, Scheet P, Abecasis GR. MaCH: using sequence and genotype data to estimate haplotypes and unobserved genotypes. Genet Epidemiol 2010;34: 816-834.

17. McCarthy S, Das S, Kretzschmar W, et al. A reference panel of 64,976 haplotypes for genotype imputation. Nat Genet 2016;48:1279-1283.

18. Lunnon K, Ibrahim Z, Proitsi P, et al. Mitochondrial dysfunction and immune activation are detectable in early Alzheimer's disease blood. J Alzheimers Dis 2012;30: 685-710.

19. Schadt EE, Woo S, Hao K. Bayesian method to predict individual SNP genotypes from gene expression data. Nat Genet 2012;44:603-608.

20. Westra HJ, Peters MJ, Esko T, et al. Systematic identification of trans eQTLs as putative drivers of known disease associations. Nat Genet 2013;45:1238-1243.

21. Benjamini Y, Hochberg Y. Controlling the false discovery rate: a practical and powerful approach to multiple testing. J R Stat Soc Series B Stat Methodol 1995;57: 289-300.

22. Giambartolomei C, Zhenli Liu J, Zhang W, et al. A Bayesian framework for multiple trait colocalization from summary association statistics. Bioinformatics 2018;34 $2538-2545$.

23. Zhu Z, Zhang $\mathrm{F}, \mathrm{Hu} \mathrm{H}$, et al. Integration of summary data from GWAS and eQTL studies predicts complex trait gene targets. Nat Genet 2016;48:481-487. 
24. Jack CR, Bernstein MA, Borowski BJ, et al. Update on the magnetic resonance imaging core of the Alzheimer's disease neuroimaging initiative. Alzheimers Dement 2010;6:212-220.

25. Risacher SL, Kim S, Nho K, et al. APOE effect on Alzheimer's disease biomarkers in older adults with significant memory concern. Alzheimers Dement 2015;11: 1417-1429.

26. Mohs RC, Knopman D, Petersen RC, et al. Development of cognitive instruments for use in clinical trials of antidementia drugs: additions to the Alzheimer's Disease Assessment Scale that broaden its scope. The Alzheimer's Disease Cooperative Study. Alzheimer Dis Assoc Disord 1997;11:S13-S21.

27. Zhao L. CD33 in Alzheimer's disease: biology, pathogenesis, and therapeutics: a minireview. Gerontology 2018;65:1-9.

28. Bradshaw EM, Ottoboni L, Rosenkrantz LL, et al. CD33 Alzheimer's disease locus: altered monocyte function and amyloid biology. Nat Neurosci 2013;16:848-850.

29. Gu BJ, Huang X, Ou A, et al. Innate phagocytosis by peripheral blood monocytes is altered in Alzheimer's disease. Acta Neuropathol 2016;132:377-389.

30. Satoh T, Arii J, Suenaga T, et al. PILRalpha is a herpes simplex virus-1 entry coreceptor that associates with glycoprotein B. Cell 2008;132:935-944.

31. Rathore N, Ramani SR, Pantua H, et al. Paired Immunoglobulin-like Type 2 Receptor Alpha G78R variant alters ligand binding and confers protection to Alzheimer's disease. PLoS Genet 2018;14:e1007427.
32. Itzhaki RF. Corroboration of a major role for herpes simplex virus type $1 \mathrm{in} \mathrm{Alz}$ heimer's disease. Front Aging Neurosci 2018;10:324.

33. Hamilton G, Harris SE, Davies G, et al. Alzheimer's disease genes are associated with measures of cognitive ageing in the lothian birth cohorts of 1921 and 1936. Int J Alzheimers Dis 2011;2011:505984.

34. Morris JK, Honea RA, Vidoni ED, Swerdlow RH, Burns JM. Is Alzheimer's disease a systemic disease? Biochim Biophys Acta 2014;1842:1340-1349.

35. Vidoni ED, Townley RA, Honea RA, Burns JM, Neuroimaging AD. Alzheimer disease biomarkers are associated with body mass index. Neurology 2011;77:1913-1920.

36. Mohr S, Liew CC. The peripheral-blood transcriptome: new insights into disease and risk assessment. Trends Mol Med 2007;13:422-432.

37. Hampel H, O'Bryant SE, Molinuevo JL, et al. Blood-based biomarkers for Alzheimer disease: mapping the road to the clinic. Nat Rev Neurol 2018;14:639-652.

38. Gligorijevic V, Malod-Dognin N, Przulj N. Integrative methods for analyzing big data in precision medicine. Proteomics 2016;16:741-758.

39. Yan J, Risacher SL, Shen L, Saykin AJ. Network approaches to systems biology analysis of complex disease: integrative methods for multi-omics data. Brief Bioinformatics 2018;19:1370-1381.

40. Park YH, Hodges A, Risacher SL, et al. Dysregulated Fc gamma receptor-mediated phagocytosis pathway in Alzheimer's disease: network-based gene expression analysis. Neurobiol Aging 2020;88:24-32. 


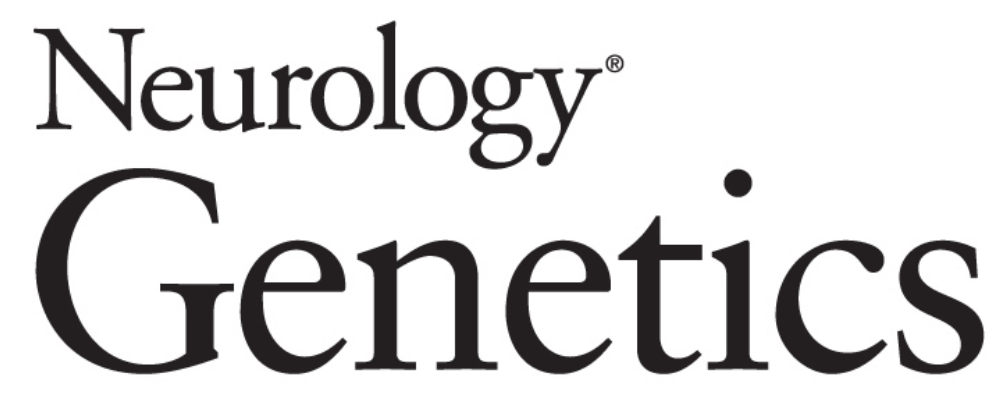

\section{Association of blood-based transcriptional risk scores with biomarkers for Alzheimer disease}

Young Ho Park, Angela Hodges, Andrew Simmons, et al. Neurol Genet 2020;6;

DOI 10.1212/NXG.0000000000000517

This information is current as of September 30, 2020

Updated Information \& Services

References

Citations

Subspecialty Collections

Permissions \& Licensing

Reprints including high resolution figures, can be found at: http://ng.neurology.org/content/6/6/e517.full.html

This article cites 40 articles, 1 of which you can access for free at: http://ng.neurology.org/content/6/6/e517.full.html\#\#ref-list-1

This article has been cited by 2 HighWire-hosted articles: http://ng.neurology.org/content/6/6/e517.full.html\#\#otherarticles

This article, along with others on similar topics, appears in the following collection(s):

Alzheimer's disease

http://ng.neurology.org//cgi/collection/alzheimers_disease

Gene expression studies

http://ng.neurology.org//cgi/collection/gene_expression_studies

Information about reproducing this article in parts (figures,tables) or in its entirety can be found online at:

http://ng.neurology.org/misc/about.xhtml\#permissions

Information about ordering reprints can be found online: http://ng.neurology.org/misc/addir.xhtml\#reprintsus

Neurol Genet is an official journal of the American Academy of Neurology. Published since April 2015, it is an open-access, online-only, continuous publication journal. Copyright Copyright $\odot 2020$ The Author(s). Published by Wolters Kluwer Health, Inc. on behalf of the American Academy of Neurology.. All rights reserved. Online ISSN: 2376-7839.

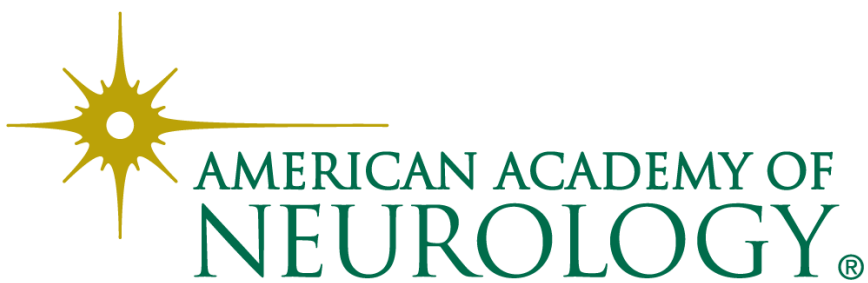

